and institutional analyses of public communications, political cognition, political discourse, rhetoric and narrative, media and political identity, and interpersonal communications.

Proposals which utilize comparative or interdisciplinary approaches or that develop new theoretical or methodological ground are particularly encouraged. When appropriate we will try to arrange co-sponsorship with other sections.

Transformational Politics. ${ }^{*}$ Stephen Woolpert, Department of Government, St. Mary's College of California, Moraga, CA 94575; (510) 376-4411, ext. 609; and Audrey Chapman, Program Director, Science and Human Rights Program, American Association for the Advancement of Science, 1333 H Street, N.W., Washington, DC 20005; (202) 326-6795.

What we mean by political transformation is when a society undergoes major change in some important part of its political attitudes, values, or institutions. The Transformational Politics section of the APSA is devoted to studying, analyzing, researching, and discussing the philosophical, theoretical, and comparative aspects of this phenomenon in general. As far as the United States is concerned, however, we believe that a transformational process is presently underway and we are not only analysts of it, but advocates and practitioners as well. We see the contemporary American movements in civil rights, feminism and ecofeminism, environmental protection, nonviolence and conflict resolution, participatory democracy, Green and New Age politics as being part of this transformational process.

We seek panels and papers that address the promise and performance of these (and other) components of this transformational process and period. Papers may be rigorous and systematic or theoretical and anecdotal. We also sponsor a series of support groups in the evenings during the APSA where we discuss our personal experiences, problems and challenges as those who practice this kind of politics as professors of political science-in the workplace, in politics and in our personal lives. Those who have experience as facilitators or mediators are en- couraged to write us about participating as such in the support groups.

Caucus for a New Political Science.* Joe Kling, Department of Government, St. Lawrence University, Canton, NY 13617; (315) 379-5214 or 379-5279.

The purpose of this section is to bring together those individuals who identify with a critical and activist approach to the study of political science. We seek papers across the broadest possible spectrum of the discipline. But we expect these papers will share the conviction that the study of politics is never value-free, and that political scientists, whatever their field or focus, have an active responsibility to connect their understanding to the search for human betterment and social justice.

While we have not decided upon a specific set of themes for the 1993 meeting, we are generally interested in the following areas:

(1) Currents in critical political theory, including discussions of NeoMarxism, Critical Theory, The Politics of Culture, Feminist Theory, and The Idea of a New Political Science.

(2) Contending Perspectives on Democracy and Development, including discussions of Latin America, Asia, Middle East, Africa, Women in the Third World.

(3) Racial and Ethnic Politics.

(4) The Politics of Gender.

(5) International Political Economy, Political Responses to the Globalization of the Economy, Intervention in Third World Politics.

(6) Urban Political Economy, Community Politics.

(7) Social Movements in Western Europe and America, Political Transformation in Communist Systems, Agendas for the Left.

If there are other topics or themes in which you would be interested, we invite your suggestions and proposals.

Political Psychology. Maryann K. Cusimano, Johns Hopkins University, Department of Political Science, Baltimore, MD 21218; (410) 516-7540 (W); (410) 889-6062 (H); Fax: (410) 516-5515.

Papers concerning the relationship between political and psychological processes are welcome, especially proposals for papers and panels which address the following topics: prospect theory; political cognition; the intersection between postmodernism and political psychology; the pros and cons of various methodologies of political psychology; crisis decision making; political psychology as a field of research-its definition, history, future, problems and promise. These suggestions are in no way meant to be exhaustive. We are also interested in panel proposals that can be jointly sponsored by any of the other organized sections.

\section{APSA Research Grantees Announced}

The APSA Research Support Committee announced the 1992 Research Grantees on May 1. The Council established the research grant program in 1984, and authorized $\$ 15,000$ to be distributed annually. To be eligible for a grant the applicants must be APSA members and must either be a faculty member at a non-Ph.D. granting college or university or be a political scientist not affiliated with an academic institution. Funds are used for research that addresses a significant problem in political science.

The Selection Committee, composed of Gary Jacobson, University of California-San Diego, chair; F. Chris Garcia, University of New Mexico; Timothy Tilton, Indiana University; Kathleen Knight, University of Houston; and Stanley Rothman, Smith College, reviewed 34 applicants and made 11 awards.

Karen Beckwith, The College of Wooster, "Women, Communities, and Political Movements in the United States and Great Britain"

Jeffrey Edwards, Roosevelt University, "The Resolution of an Urban Crisis: Racial Formation in Detroit, 1961-1981"

James M. Glaser, Tufts University, "Studying Political and Racial Attitudes with Contextual Data"

Robert J. Griffiths, University of North Carolina-Greensboro, "The South African Armed Forces: Democratization and Reorganization"

Rebekah Herrick, Oklahoma State 
University, "Political Ambition"

Theresa Marchant-Shapiro, Union College, "With a Finger to the Wind: Primary Candidates' Strategic Use of Issues"

Jeffrey Ian Ross, University of Lethbridge, "The Other Side of the Big Six: Politics and Control of Police Violence in Major American Cities"

Richard Stahler-Sholk, Pitzer College, "Debt, Adjustment, and Organized Labor: Problems of Democratization in Nicaragua"

Yuan Ting, Oakland University, "An Analysis of the Impact of AFDC Benefit Levels on the Interstate Migration of AFDC Recipients"

Daniel Wirls, University of California-Santa Cruz, "Explaining Senate Elections: The Problems of Mixed-Party Delegations"

Voytek Zubek, University of Alabama-Birmingham, "The Crystallization of Poland's Party System"

\section{Ralph Bunche Summer Institute}

Twenty-five juniors who have demonstrated interest and potential in the field of political science participated in the seventh annual Ralph Bunche APSA Summer Institute in Political Science for Black Students, held June 8-July 18 in Atlanta, Georgia.

The Institute was conducted by a consortium consisting of Spelman College, Morehouse College, Georgia State University, Clark-Atlanta University and Emory University. Lois Moreland of Spelman College was director of the 1992 institute. Roger Miller of Georgia State, Eleanor Main and Micheal Giles of Emory University, Tobe Johnson of Morehouse College, and William Boone of Clark-Atlanta University were coordinators of their respective campuses.

The students selected as institute participants came from diverse universities and colleges from 18 different states and the District of Columbia.

Craig M. Brodhead, State University of New York

Ernecia S. Coles, University of Virginia
Amy D. Donaldson, University of Alabama

Melissa N. Doss, Trenton State College

Jared K. Ellison, Tuskegee University

James R. Freeman, University of California, Santa Barbara

David A. Glass, Lock Haven University

Erika L. Gordon, Spelman College

Thomasine Gore, St. Augustine College

Julian Guillroy, Southern University

Bridget L. Hardaway, West Georgia College

Ayanna B. Hobbs, Drake University

Lisa M. Howard, Bethune-Cookman College

Shawtrice L. Jackson, Cornell

University

Robert James, Marquette University

Adrian M. Lewis, Tennessee State University

Eric P. Martin, Baldwin-Wallace College

Eric J. Narcisse, University of Texas

Enette Nelson, University of South Florida

John T. O'Neal, University of North Carolina, Chapel Hill

Nancy M. Pretto, Howard University

Tamara T. Saduddin-Singh, University of South Carolina

Kimberly M. Smith, Tufts University

Fred Shotlow, Jr., Northeastern University

Tamelyn N. Tucker, Hampton University

The six-week program consisted of two graduate level courses taught on two of the campuses of the member institutions. Each participant also completed a research project integrating the two courses. The project involved original, empirical research. Academic credit for successful completion of the courses was awarded by Spelman College.

Students also participated in a series of lectures and workshops. These included: sessions where prominent political scientists discussed their work, a workshop that focused on the Graduate Record Exam, and sessions with recruiters of graduate programs from leading institutions.

\section{The American Political Science Association Policy and Procedures for Permission to Reprint Articles, * 1992}

The author of the material to be reprinted is free to give or deny permission, or to impose conditions, fees or a share of royalties. In all cases, the author's permission must be requested. Reprinting material without permission and/or without full attribution is a violation of the Association's code of professional ethics.

The Association, upon receiving a request to reprint an article, informs the requester that a detailed response will be forthcoming after the Association contacts the author or authors. At the same time, the publisher is asked for information about the intended publication, its audience, and whether or not the article will be edited. Upon receipt of this information, the APSA notifies the author of the request, conveys the information provided by the publisher, and asks the author to complete a form, noting whether or not permission is given and the conditions under which it will be given.

A response is then made to the person requesting permission to reprint, informing him/her of the author's wishes. A normal fee specified by authors is $\$ 200$. (That fee is often shared when more than one author has written an article.) The Association requests a fee of $\$ 100$ for each article or major portion thereof, for commercial use. These fees are waived for an author seeking permission to reprint his/her own article(s).

The Association also requires that a request be submitted when a publisher seeks to reprint a table or a figure from an article or any segment of an article that is 1,000 words or

*This statement pertains to material to be reprinted in books and bound volumes and not to material to be copied or reproduced for class use. The APSA has a separate policy regarding granting permission to copy articles for classroom use. 